\title{
Genetic analysis of methicillin-resistant Staphylococcus aureus from a Nigerian hospital
}

\author{
E. E. UDO and W. B. GRUBB* \\ School of Biomedical Sciences, Curtin University of Technology, GPO Box U 1987, Perth 6001, Western Australia
}

\begin{abstract}
Summary. Methicillin-resistant strains of Staphylococcus aureus isolated during 1985 and 1987 at a Nigerian hospital were compared by resistance profiles, plasmid analysis, and pulsed-field gel electrophoresis of chromosomal DNA. The results indicated that the isolates from the two periods were unrelated with regard to all three aspects. None of the isolates was similar to the classical MRSA nor to the epidemic MRSA of Australia or the UK. The MRSA isolated in 1985 had a similar plasmid to MRSA isolates from Singapore, but differed from them when compared by pulsed-field gel electrophoresis.
\end{abstract}

\section{Introduction}

Multi-resistant Staphylococcus aureus continue to be a major cause of serious infections in man, both in hospitals and in the community. ${ }^{1}$ Since they were first reported in the UK in $1961,{ }^{2-4}$ methicillin-resistant $S$. aureus (MRSA) have been found in many countries, including Britain, ${ }^{5}$ France, ${ }^{6}$ USA, $^{7}$ Ireland ${ }^{8,9}$ and Australia. ${ }^{10}$ MRSA are important clinically because their resistance to methicillin confers cross-resistance to other $\beta$-lactam antibiotics, including cephalosporins. In addition, MRSA are frequently resistant to most other antimicrobial agents except vancomycin. ${ }^{11}$

MRSA isolated in the UK, Europe and Australia until the early 1970 s shared common characteristics. ${ }^{12-15}$ Typically, they had high-level chromosomal resistance to streptomycin and inducible resistance to erythromycin. They contained two plasmids: one of c. $30 \mathrm{~kb}$, encoding penicillinase and resistance to heavy metals, and one of $4.4 \mathrm{~kb}$, encoding tetracycline resistance. ${ }^{15}$ These isolates have been described as the "classic" MRSA. ${ }^{15}$ Genetic studies on MRSA isolates from Eastern Australian hospitals in the 1980s (EA MRSA) revealed differences from the classic MRSA. ${ }^{13-15}$ EA MRSA typically have chromosomal determinants for penicillinase and resistance to heavy metals, tetracycline, minocycline, streptomycin (lowlevel) together with inducible resistance to erythromycin and lincomycin. They usually carry three plasmids: a cryptic plasmid $(c .1 .8 \mathrm{~kb})$, a chloramphenicol-resistance plasmid $(c .4 .5 \mathrm{~kb})$ and a $c .28-\mathrm{kb}$ incompatibility group 1 plasmid, that encodes resistance to nucleic acid binding compounds and, sometimes, gentamicin, kanamycin and trimethoprim, together with penicillinase production. ${ }^{15}$ MRSA

Received 2 June 1982; revised version accepted 17 Aug. 1992.

* Correspondence should be sent to Professor W. B. Grubb. resembling the EA MRSA have also been reported in some London hospitals. ${ }^{16}$ The similarity of the London and EA MRSA has been confirmed by examining the chromosomal DNA of the isolates with an $\mathrm{M} 13$ repeat probe ${ }^{17}$ and by pulsed-field gel electrophoresis. $^{18}$

Despite the widespread incidence of MRSA in many parts of the world, they have been reported only recently in Nigerian hospitals. ${ }^{19,20}$ In a study of antibiotic resistance in S. aureus isolated at the Lagos University Teaching Hospital (LUTH) in 1985, <2\% of the isolates were methicillin-resistant (Udo and Grubb, unpublished results). By 1987, however, $50 \%$ of the $S$. aureus isolates at this hospital were methicillin-resistant. ${ }^{19}$ Seven of the 42 MRSA then collected were resistant to multiple antibiotics and were described as epidemic strains. ${ }^{19}$ This paper reports the genetic study of these seven isolates in comparison to one organism isolated at the same hospital in 1985. The isolates were also compared with MRSA from others parts of the world.

\section{Materials and methods}

\section{Bacteria and plasmids}

The isolates and reference strains studied are listed in the table.

\section{Media and reagents}

Brain Heart Infusion Broth (BHIB), Brain Heart Infusion Agar (BHIA), Trypticase Soy Broth (TSB) and Mueller Hinton Agar (MHA) were purchased from Gibco Diagnostics (Madison, WI, USA). Lysostaphin, ribonuclease $\mathrm{A}$ and proteinase $\mathrm{K}$ were purchased from Sigma. SmaI restriction endonuclease 
duction. All strains were maintained by twice-weekly subculture on to Columbia blood agar and Skirrow's agar.

Growth of bacteria in broth cultures. Surface bacterial growth on a Columbia blood agar plate was harvested with a sterile swab and suspended in $5 \mathrm{ml}$ of sterile saline $0.9 \%$ to form a concentrated suspension. A 1-ml inoculum was added to Brain Heart Infusion Broth (BHIB, Oxoid) supplemented with fetal calf serum (Flow Laboratories, Irvine) $8 \%$, and vancomycin (AddaTab, Mast Laboratories, Bootle) $6.7 \mathrm{mg} / \mathrm{L}$. The cultures were grown as shallow layers, 2-3 $\mathrm{ml}$ deep, in petri dishes (Bibby Sterilin, Stone) with the side walls perforated just below the lid, to promote gas exchange during incubation.

The cultures were incubated at $37^{\circ} \mathrm{C}$ for $72 \mathrm{~h}$ under micro-aerophilic conditions. The purity of each culture was checked by Gram's stain and urease activity. Bacteria were harvested by centrifugation at $2500 \mathrm{~g}$ for $10 \mathrm{~min}$, and washed three times in saline $0.9 \%$.

Preparation of radiolabelled bacteria. Bacteria were grown in supplemented BHIB, containing ${ }^{3} \mathrm{H}$ adenine $10 \mu \mathrm{l} / 10 \mathrm{ml}$ of broth. Uptake of radiolabel was satisfactory after incubation for $72 \mathrm{~h}$. The bacteria were harvested by centrifugation at $750 \mathrm{~g}$ for $15 \mathrm{~min}$, washed three times with phosphate-buffered saline (PBS), $\mathrm{pH} \mathrm{7,} \mathrm{and} \mathrm{suspended} \mathrm{in} \mathrm{saline} 0.9 \%$ to give an $\mathrm{OD}_{610}$ of $0 \cdot 13$, which had been demonstrated previously to be equivalent to a viable count of $1 \times 10^{7} \mathrm{cfu} / \mathrm{ml}$.

\section{Opsonisation of bacteria}

A single pool of normal human serum (NHS) was derived from the blood of $c .20$ healthy laboratory workers, and stored in small quantities at $-70^{\circ} \mathrm{C}$ until use. NHS was assayed for anti- $H$. pylori surface antigen and anti-urease specific antibody by ELISA $^{9,10}$ at the Public Health Laboratory, Preston. $H$. pylori antibody titres varied between 2000 and 4000 , and urease antibody titres between 2000 and 8000 .

NHS was diluted in Hanks's Balanced Salts Solution $10 \%$ supplemented with gelatin $0 \cdot 1 \%$ (GHBSS) to obtain various serum concentrations. Complement activity was destroyed by heating NHS to $56^{\circ} \mathrm{C}$ for $30 \mathrm{~min}$ and the alternative pathway activity was destroyed by heating NHS to $50^{\circ} \mathrm{C}$ for 30 min. ${ }^{11}$ Components of the classical pathway were blocked by treating NHS with ethylene glycol-bis $(\beta$-aminoethyl ether)-N, $\mathrm{N}^{\prime}$-tetra-acetic acid (final concentration $10 \mathrm{mM}$ ) in the presence of equimolar $\mathrm{MgCl}_{2}$ (EGTA$\left.\mathrm{MgCl}_{2}\right){ }^{12}$

$H$. pylori-specific antibody was removed by triple absorption against a pool of three strains of $\boldsymbol{H}$. pylori at $0^{\circ} \mathrm{C}$ for $15 \mathrm{~min}$. Titres of $H$. pylori antibody fell by between four- and eight- fold and anti-urease antibody titres by between eight- and 32-fold. Specific antibody and complement were removed by sequential heating and absorption. In some experiments, serum absorbed with $H$. pylori was further treated by triple absorption $\left(0^{\circ} \mathrm{C}\right.$ for $\left.15 \mathrm{~min}\right)$ with Staphylococcus aureus (Cowan 1 strain) as a source of protein A. Protein A binds to the $\mathrm{Fc}$ region, inactivating immunoglobulin irrespective of antigenic specificity. ${ }^{13}$

Suspensions of $H$. pylori in saline $0.9 \%$ were adjusted to either an $\mathrm{OD}_{610}$ of $0 \cdot 13$ (viable count ${ }^{4} 1 \times 10^{7} \mathrm{cfu}$ ) for the radiolabelled bacterial experiments, or $\mathrm{OD}_{610}$ of 0.3 (viable count $2 \times 10^{7} \mathrm{cfu}$ ) for the assessment of PMNL chemiluminescence. Equal quantities of bacterial suspension and NHS diluted in GHBSS were mixed and incubated at $37^{\circ} \mathrm{C}$ for $15 \mathrm{~min}$ in a rotary incubator. The bacteria were sedimented by centrifugation at $2500 \mathrm{~g}$ for $15 \mathrm{~min}$ and resuspended in their original volume in GHBSS. Opsonised bacteria were used immediately.

\section{Preparation of PMNL}

PMNL were freshly prepared for each experiment, by a method based on that of Böyum. ${ }^{14}$ Sixty $\mathrm{ml}$ of heparinised blood was taken from a series of healthy volunteers and mixed with $20 \mathrm{ml}$ of dextran 150 in saline $0.9 \%$ for $30 \mathrm{~min}$ to sediment erythrocytes. Ten-ml volumes of leucocyte-rich supernate were decanted into conical centrifuge tubes containing 3-5 $\mathrm{ml}$ of Leucocyte Separation Medium (Flow Laboratories) and centrifuged at $750 \mathrm{~g}$ for $30 \mathrm{~min}$. The PMNL-rich layer was then resuspended in $\mathrm{NH}_{4} \mathrm{Cl}$ $0.87 \%$ to lyse any remaining red blood cells. PMNL were washed in GHBSS and resuspended to a concentration of $2 \times 10^{7} \mathrm{PMNL} / \mathrm{ml}$. In all experiments PMNL were used within $3 \mathrm{~h}$ of separation.

\section{Measurement of phagocytosis by uptake of radiolabelled bacteria}

The method was based on that previously described by Verhoef $e t$ al. ${ }^{15}$ in which each experimental limb consisted of a set of four reaction mixtures. Two of the four contained $0.1 \mathrm{ml}$ of opsonised bacteria in GHBSS and an equal volume of PMNL. The other two contained $0.1 \mathrm{ml}$ of bacteria with an equal volume of GHBSS but no PMNL. These acted as controls, allowing an estimate to be made of any non-specific binding of bacteria to the walls of the reaction vessels. Each experimental limb was performed in duplicate. After incubation at $37^{\circ} \mathrm{C}$ for $15 \mathrm{~min}$, one vial containing PMNL (washed cells) and one containing GHBSS alone (control) were centrifuged at $750 \mathrm{~g}$ for 5 min to pellet the PMNL; unphagocytosed bacteria remained in suspension and were discarded with the supernate. Pellets were washed three times in ice-cold PBS to remove extracellular radiolabel, and then scintillation fluid (Canberra Packard, Caversham) was added to lyse all the remaining cells. The remaining two vials had scintillant added immediately after incubation to produce an estimate of the total radiolabel present (total count).

The radioactivity of each sample was measured in an "Ultrabeta" scintillation counter (LKB, Milton 
each dilution was spread on to selective media, as in mixed-culture transfer.

In both mixed-culture and conjugation experiments, controls consisting of donor and recipient only were used. Transfer was considered to have occurred when growth was obtained on selective plates from the donor plus recipient mixtures and not on selective media plated with either organism alone.

\section{Plasmid isolation}

Plasmid extracts suitable for restriction endonuclease analysis were isolated by the cetyltrimethylammonium bromide method. ${ }^{25}$ Horizontal agarose gel electrophoresis and restriction enzyme analysis were performed as described previously. ${ }^{23}$

\section{Pulsed-field gel electrophoresis}

Electrophoresis of DNA was performed by the contour-clamped homogeneous electric field (CHEF) method. Cells were treated as reported previously, ${ }^{18}$ though with some modifications. They were grown overnight in $5 \mathrm{ml}$ of $\mathrm{BHIB}$ at $35^{\circ} \mathrm{C}$, washed twice in $10 \mathrm{ml}$ of $50 \mathrm{~mm}$ EDTA, $\mathrm{pH} 8.0$, and resuspended in $6 \mathrm{ml}$ of EC buffer-6 $\mathrm{mm}$ Tris; $1 \mathrm{M} \mathrm{NaCl} ; 100 \mathrm{~mm}$ EDTA; Brij 58 (Sigma) 0.5\%, sodium deoxycholate $0 \cdot 2 \%$, sodium lauroylsarcosine $0.5 \%, \mathrm{pH} 7 \cdot 5 .^{26}$ The cell density was then adjusted to $c .3 \times 10^{8} \mathrm{cfu} / \mathrm{ml}$. Equal volumes of this suspension and agarose (Sigma type 1, A-6013) $1 \% \mathrm{w} / \mathrm{v}$ were mixed and aspirated into glass capillary tubes (diameter, $1.6 \mathrm{~mm}$ ). After these plugs had solidified, $c .1 \mathrm{~cm}$ was expelled into $200 \mu \mathrm{l}$ of lysing solution (lysostaphin $200 \mathrm{mg} / \mathrm{L}$ in $50 \mathrm{~mm}$ EDTA) and incubated at $37^{\circ} \mathrm{C}$ for at least $4 \mathrm{~h}$. The plugs were then held overnight at $50^{\circ} \mathrm{C}$ in $200 \mu \mathrm{l}$ of EST buffer ( $0.5 \mathrm{~m}$ EDTA, $5 \mathrm{~mm}$ Tris, sodium lauroylsarcosine, $1 \%$, $\mathrm{pH} 7.5$ ) containing proteinase $\mathrm{K}$, $20 \mathrm{~g} / \mathrm{L}$, then washed three times for $2 \mathrm{~h}$ in $50 \mathrm{~mm}$ EDTA at room temperature and stored at $4^{\circ} \mathrm{C}$ in $50 \mathrm{~mm}$ EDTA until used. Before use, the plugs were digested with SmaI restriction endonuclease, according to the supplier's instructions, and inserted into wells of an agarose (Sigma Type 1, A-6013) 1\% gel. Electrophoresis was performed with a CHEF-DR II system (BioRad Laboratories, Richmond CA, USA) at $4^{\circ} \mathrm{C}$ for $42 \mathrm{~h}$ in half-strength TBE buffer $(45 \mathrm{mM}$ Tris, $45 \mathrm{~mm}$ boric acid, $1 \mathrm{~mm}$ EDTA, pH 8.0) at $120 \mathrm{~V}$. The pulse times were $10 \mathrm{~s}$ initial and $80 \mathrm{~s}$ final.

\section{Results}

\section{Characteristics of the isolates}

The seven isolates obtained in 1987-WBG7208, WBG7209, WBG7210, WBG7211, WBG7212, WBG7213 and WBG7214 all belonged to phage group III. ${ }^{19}$ They all produced penicillinase and were resistant to methicillin, kanamycin, neomycin, streptomycin, tetracycline and cadmium. They harboured a single plasmid of c. $30 \mathrm{~kb}$ (fig. 1).

Strain WBG4763, isolated in 1985, had the phage pattern 53/85, harboured a single plasmid of $c .30 \mathrm{~kb}$, produced penicillinase and was resistant to methicillin, gentamicin, kanamycin, neomycin, streptomycin, tetracycline, minocycline, cadmium, mercury, phenyl mercuric acetate and the nucleic acid binding compounds, propamidine isethionate and ethidium bromide. All the isolates were susceptible to mupirocin and vancomycin.

\section{Plasmid analysis}

During the curing experiments, only cadmium resistance was lost from the seven 1987 isolates. Its loss correlated with the disappearance of the $30-\mathrm{kb}$ plasmid. Of 168 colonies of the 1985 isolate, WBG4763, screened for loss of resistance, one lost methicillin resistance and four lost resistance to cadmium, mercury, phenyl mercuric acetate, propamidine isethionate and ethidium bromide. Loss of resistance to the last four compounds corresponded to the disappearance of the $30-\mathrm{kb}$ plasmid, but the loss of methicillin resistance appeared to be independent of plasmid loss. To test further whether methicillin resistance was associated with the plasmid, extrachromosomal DNA was isolated from strain WBG4763 and its methicillinsusceptible derivative (WBG6198) and digested with EcoRI restriction endonuclease. The fragments thereby generated were identical (not shown), con-

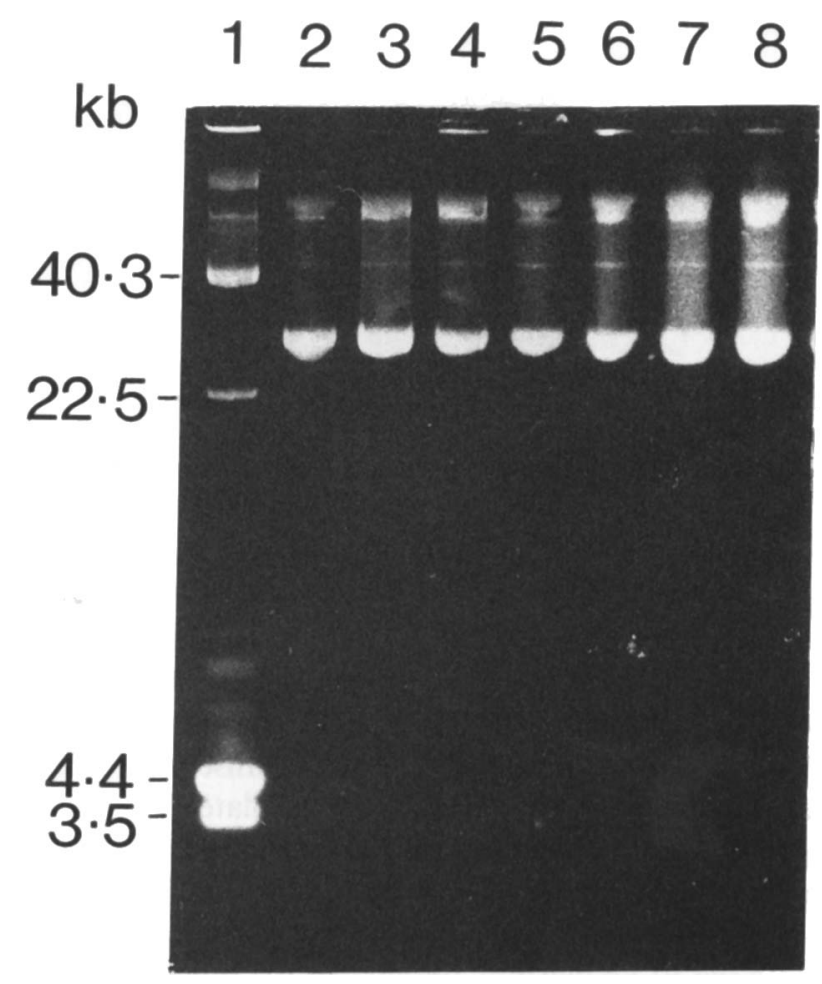

Fig. 1. Plasmid content of the isolates obtained in 1987. Lane 1, WBG4483, contains plasmid mol. wt markers; 2, WBG7208; 3, WBG7209; 4, WBG7210; 5, WBG7211; 6, WBG7212; 7, WBG7213;8, WBG7214. 


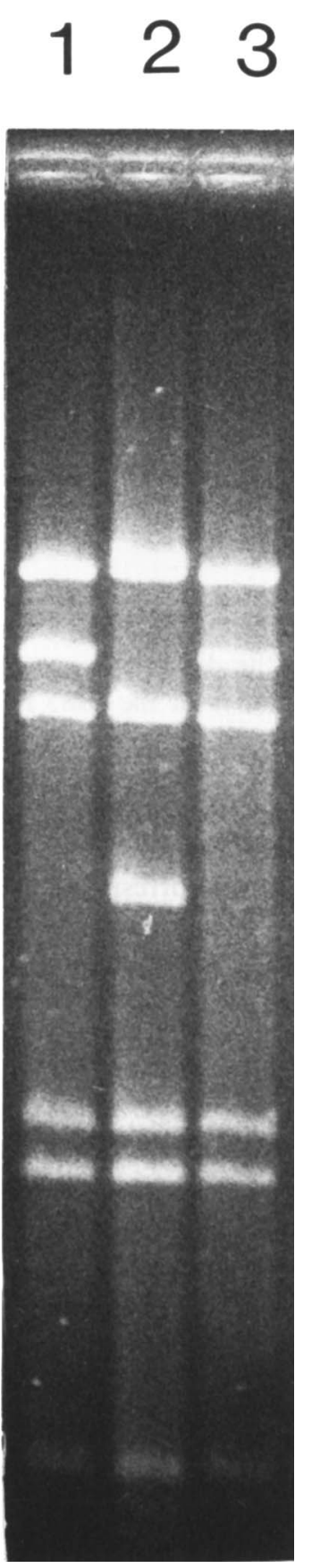

Fig. 2. EcoRI restriction enzyme analysis of plasmid pWBG663 from the Nigerian isolate WBG4763 with plasmids from Singaporean MRSA. Lane 1, pWBG663; 2, pWBG278; 3, pWBG281.

firming that the methicillin-resistance determinant was not located on the plasmid.

To study the isolates further, their plasmids were transferred to WBG1876 by mixed-culture transfer. Only cadmium resistance was transferred from WBG7208 to WBG7214. Their transcipients had acquired the $30-\mathrm{kb}$ plasmid. With isolate WBG4763, penicillinase production and resistance to cadmium, mercury, phenylmercuric acetate, propamidine isethionate and ethidium bromide were transferred together with the 30-kb plasmid, designated pWBG663. Methicillin resistance was not transferred. None of the isolates transferred any of their resistance determinants to WBG541 by conjugation.
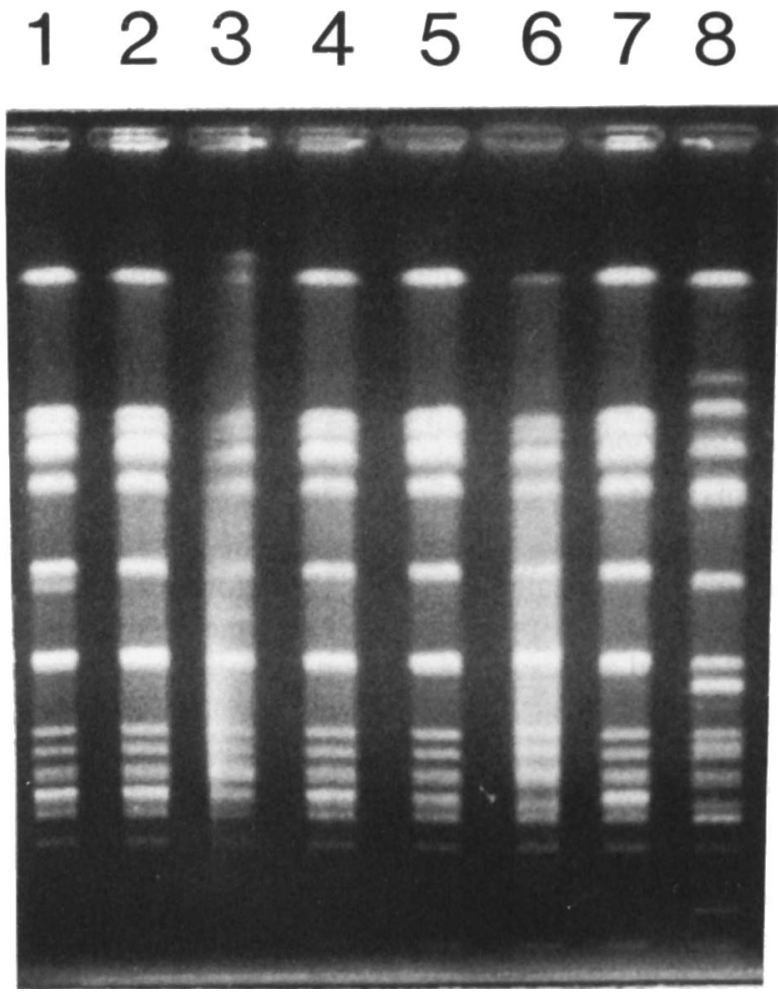

Fig. 3. SmaI restriction enzyme analysis of chromosomal DNA from the isolates. Lane 1, WBG7208; 2, WBG7209;3, WBG7210;4, WBG7211;5, WBG7212;6, WBG7213;7, WBG7214;8, WBG1437 (classic MRSA).

Plasmid pWBG663 carried resistances identical to those of the plasmids found in MRSA isolates WBG1983 and WBG1997, which were obtained in Singaporean hospitals. ${ }^{27}$ EcoRI restriction digests of the plasmid pWBG663 and two plasmids, pWBG278 and pWBG281, from WBG1983 and WBG1997, respectively, revealed that they were closely related (fig. 2).

\section{MICs of streptomycin}

The MICs of streptomycin for all the LUTH isolates, including WBG4763, were $>2000 \mathrm{mg} / \mathrm{L}$.

\section{Analysis of chromosomal DNA}

Smal digests of the chromosomal DNA of all the isolates were analysed by pulsed-field gel electrophoresis (figs. 3 and 4). The 1987 isolates WBG7208 to WBG7214 inclusive had similar Smal restriction patterns (fig. 3) and were different from the classic MRSA (WBG1437), WBG4763 and its methicillin-susceptible derivative WBG6198 (fig. 4) and from the EA MRSA (WBG525) (not shown).

As restriction enzyme analysis had suggested that plasmid pWBG663 from strain WBG4763 was related to the two plasmids from the Singaporean MRSA, the chromosomes of the two Singaporean MRSA were compared with that of WBG4763 and its methicillinsensitive derivative, WBG6198. No relatedness was demonstrated (fig. 4).

Derivative WBG6198 lacked a 210-kb SmaI frag- 


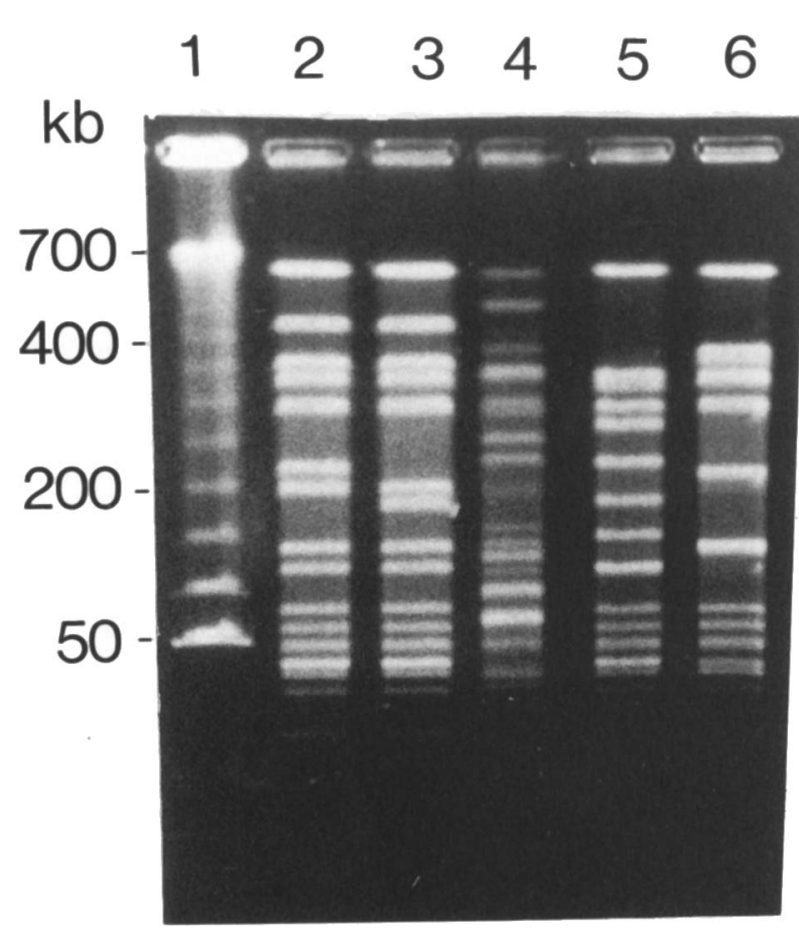

Fig. 4. SmaI restriction enzyme analysis of isolates and their derivatives. Lane 1, lambda concatemers; 2, WBG4763; 3, WBG6198; 4, WBG1983; 5, WBG1997; 6, WBG7208. Note that WBG6198 has lost a $210-\mathrm{kb}$ band and gained a $170-\mathrm{kb}$ band, as compared to WBG4763.

ment present in WBG4763 but had a 170 -kb fragment absent from WBG4763 (fig. 4). As this was the only difference observed between the two organisms, it follows that the appearance of the $170-\mathrm{kb}$ fragment in WBG6198 resulted from the loss of $40 \mathrm{~kb}$ of DNA from the $210-\mathrm{kb}$ fragment in WBG4763. This loss corresponded to the loss of methicillin resistance.

\section{Discussion}

Until 1987, there were no reports of MRSA from Nigeria, nor any indication that this organism was being sought by clinical laboratories. ${ }^{28-31}$ Consequently, it is difficult to ascertain whether the subsequent reports of MRSA reflect its recent introduction, or recent awareness of the importance of testing for methicillin resistance. A study of 53 drugresistant $S$. aureus from LUTH in 1985 detected only one MRSA isolate (Udo and Grubb, unpublished results). A survey 2 years later at the same hospital reported that $50 \%$ of $S$. aureus isolates were MRSA. ${ }^{19}$ Although the 1987 survey was carried out only on patients of high risk of colonisation and infection, ${ }^{19}$ it nevertheless indicated an alarming increase in the incidence of MRSA. The 1985 MRSA isolate, WBG4763, had similar chromosomally-mediated resistances to the 1987 isolates, differing only in being resistant to minocycline and gentamicin and in carrying a different $30-\mathrm{kb}$ plasmid.

None of the Nigerian isolates resembled classic MRSA $:{ }^{15}$ although they shared this organism's highlevel resistance to streptomycin, ${ }^{32}$ they differed in being susceptible to erythromycin and in having chromosomal resistance determinants to penicillin, kanamycin and neomycin. Moreover, they lacked the plasmids coding resistance to tetracycline and heavy metals. All had chromosomal tetracycline resistance which, although not typical of classic MRSA, has been reported for a few European isolates. ${ }^{33,34}$ The LUTH isolates were also quite different from the EA MRSA of Australia and the EMRSA of the UK in that they did not have chromosomal resistance to cadmium, mercury, phenylmercuric acetate, erythromycin and lincomycin nor, except for strain WBG4763, to tetracycline and minocycline. Also, they did not have the cryptic plasmid, the chloramphenicol-resistance plasmid or the nucleic acid binding compound- trimethoprim-gentamicin-resistance plasmid typical of EA MRSA. ${ }^{15}$ Isolate WBG4763 did have a resistance profile and a nucleic acid binding compound resistance plasmid similar to some Singaporean MRSA strains. However, WBG4763 was found to differ from these Singaporean isolates when its DNA was examined by pulsed-field gel electrophoresis. It was also different from the later LUTH isolates, which closely resembled one another.

Loss of methicillin resistance from isolate WBG4763 corresponded to the loss of $c .40 \mathrm{~kb}$ of DNA (fig. 4). This figure is high compared with the values reported by others. ${ }^{35,36}$ Also, these reports found other resistance phenotypes, such as resistance to cadmium, mercury and tetracycline, to be lost together with methicillin resistance whereas no other resistance phenotype was lost with methicillin resistance from WBG4763.

The LUTH isolates were resistant to kanamycin, neomycin and streptomycin. It will be interesting to determine whether these resistances are encoded by a transposon similar to $\mathrm{Tn} 3854$, already described from a Nigerian $S$. aureus isolate. ${ }^{37}$ As mixed-culture transfer and curing experiments have demonstrated that WBG4763 has both chromosomal and plasmid-borne penicillinase determinants, it will be interesting to determine whether there is a duplication of the penicillinase determinant due to a penicillinase transposon.

This report is the first genetic analysis of Nigerian MRSA and indicates that a strain of MRSA was dominant in a Nigerian hospital and that this strain was different from other MRSA studied by the same methods. ${ }^{15}$ Whether this strain occurs in other Nigerian hospitals is not yet known.

We thank Professor V. O. Rotimi for providing the isolates. This work was supported by a National Health and Medical Research grant to W.B.G. 


\section{References}

1. Shanson DC. Antibiotic-resistant Staphylococcus aureus. J Hosp Infect 1981 : 2: $11-36$

2. Jevons PM. Celbenin-resistant staphylococci. Br Med Bull $1961 ; 1: 124-125$

3. Barber M. Methicillin-resistant staphylococci. J Clin Pathol $1961 ; 14: 385-393$.

4. Knox R. Celbenin-resistant staphylococci. Br Med Bull 1961; 1: 126.

5. Selkon JB, Stokes ER, Ingham HR. The role of an isolation unit in the control of hospital infection with methicillin-resistant staphylococci. J Hosp Infect 1980; $1: 4146$.

6. El Solh N, Fouace JM, Pillet J, Chabbert YA. Plasmid DNA content of multi-resistant Staphylococcus aureus strains. Ann Microbiol (Paris) 1981; 132B: 131-156.

7. Haley RW, Hightower AW, Khabbaz RF et al. The emergence of methicillin-resistant Staphylococcus aureus in United States hospitals. Ann Intern Med 1982; 97: 297-308.

8. Cafferkey MT, Hone R, Falkiner FR, Keane CT, Pomeroy H. Gentamicin and methicillin-resistant Staphylococcus aureus in Dublin hospitals: clinical and laboratory studies. J Med Microbiol 1983; 16:117-127.

9. Coleman DC, Pomeroy H, Estridge JK et al. Susceptibility to antimicrobial agents and analysis of plasmids in gentamicin- and methicillin-resistant Staphylococcus aureus from Dublin hospitals. J Med Microbiol 1985; 20; 157-167.

10. Pavillard R. Harvey K. Douglas D et al. Epidemic of hospitalacquired infection due to methicillin-resistant Staphylococcus aureus in major Victorian hospitals. Med $J$ Aus $1982 ; 1: 451-454$

11. Wenzel RP. The emergence of methicillin-resistant Staphylococcus aureus. Ann Intern Med 1982; 97: 440.442.

12. Lacey RW, Grinsted J. Genetic analysis of methicillin-resistant strains of Staphylococcus aureus, evidence for their evolution from a single clone. J Med Microbiol 1973; 6: $511-526$

13. Lyon BR, luorio JL, May JW, Skurray RA. Molecular epidemiology of multiresistant Staphylococcus aureus in Australian hospitals. J Med Microbiol 1984: 17: 79 - 89.

14. Townsend DE, Grubb WB, Ashdown N. Genetics of drug resistance in methicillin-resistant Staphylococcus aureus from Australian hospitals. J Hosp Infect 1983; 4: 331-337.

15. Grubb WB. Molecular epidemiology of methicillin-resistant Staphylococcus aureus. In: Novick RN (ed) Molecular biology of staphylococci. New York, VCH Publishers. 1990: 595606 .

16. Townsend DE, Ashdown N, Bolton S et al. The international spread of methicillin-resistant Staphylococcus aureus. $J$ Hosp Infect 1987; 9: 60-71.

17. Wei M-Q, Groth DM, Mendis AHW, Sampsom J, Wetherall JD, Grubb WB. Typing of methicillin-resistant Staphylococcus aureus with a $\mathrm{M} 13$ repeat probe. J Hosp Infect $1992 ; 20: 233 \cdots 245$.

18. Wei M-Q, Wang F, Grubb WB. Use of contour-clamped homogeneous electric field electrophoresis to type methicillin-resistant Staphylococcus aureus. J Med Microbiol 1992; 36: 172-176.

19. Rotimi VO, Orebamjo OA, Banjo TO, Onyenefa PI, Nwobu RN. Occurrence and antibiotic susceptibility profiles of methicillin-resistant Staphylococcus aureus in Lagos University Teaching Hospital. Cent Afr J Med 1987:33:95-99.

20. Ako-Nai AK, Oguniyi AD, Lamikanra A. Torimiro SEA. The characterisation of clinical isolates of Staphylococcus aureus in Ile-Ife Nigeria. J Med Microbiol 1991; 34 $109-112$.

21. Townsend DE, Grubb WB, Ashdown N. Gentamicin resistance in methicillin resistant Staphylococcus aureus. Pathology $1983 ; 15: 169-174$.

22. Annear DI, Grubb WB. Linked and unstable resistance to kanamycin and penicillin and diffusible pigment production, in an isolate of Staphylococcus aureus. $\mathrm{J} \mathrm{Med}$ Microbiol 1972; 5: 109-111.

23. Udo EE, Grubb WB. Excision of a conjugative plasmid from the staphylococcal chromosome. J Med Microbiol 1990 33: $227-234$

24. O'Callaghan CH, Morris A, Kirby SM, Shingler AH. Novel method for detection of beta-lactamase by using a chromogenic cephalosporin substrate. Antimicrob Agents Chemother 1972; 1: 283-288.

25. Townsend DE, Ashdown N, Bolton S, Grubb WB. The use of cetyltrimethylammonium bromide for the isolation from Staphylococcus aureus of relaxable and non relaxable plasmid DNA for in vitro manipulation. Lett Appl Microbiol $1985 ; 1: 87-94$

26. Truchsis M, Wolfson JS, Hooper DC. A novel locus conferring fluoroquinolone resistance in Staphylococcus aureus. Bacteriol 1991; 173: 5854-5860.

27. Grubb WB, Townsend DE, Ashdown N, Tjia T, McGlashan C, Leng T. Genetic analysis of methicillin-resistant Staphylococcus aureus from Singapore hospitals. Eur $J$ Clin Microbiol 1986; 5: 728-730.

28. Utsalo SJ. Characterisation of hospital and community strains of Staphylococcus aureus for resistance to antimicrobial drugs, metallic ions, disinfectants, thermal injury and solar radiation. Acta Microbiol Hung 1986; 33: 183-191.

29. Wemambu SNC. Wound infections and nasal colonisation of staff with Staphylococcus aureus in Benin, Nigeria. $J$ Hosp Infect 1981 ; 2: 259-260.

30. Rotimi VO, Odugbemi TO, Fadahunsi O, Ogunbi O. Penicillin resistance in Staphylococcus aureus: prevalence of penicillinase producing strains in Lagos University Teaching Hospital. Nig Med J 1979; 9: 307-310.

31. Nwobu RA, Ogunbi OO, Rotimi VO. Phage-types and resistance pattern of Staphylococcus aureus isolated from clinical specimens to penicillin and cloxacillin in a Lagos hospital. Cent Afr J Med 1986; 32: 155-158.

32. Grinsted J, Lacey RW. Genetic variation of streptomycin resistance in clinical strains of Staphylococcus aureus. $J$ Med Microbiol 1973; 6: 351-361.

33. Kayser FH, Wust J, Corrodi P. Transduction and elimination of resistance determinants in methicillin-resistant Staphylococcus aureus. Antimicrob Agents Chemother 1972; 2: 217-223.

34. Kayser FH, Wust J, Santanam P. Genetic and molecular characterisation of resistance determinants in methicillinresistant Staphylococcus aureus. J Med Microbiol 1976; 9 $137-147$.

35. Matthews PR, Reed KC, Stewart PR. The cloning of chromosomal DNA associated with methicillin and other resistances in Staphylococcus aureus. J Gen Microbiol 1987 133: 1919-1929.

36. Beck WD, Berger-Bachi B, Kayser FH. Additional DNA in methicillin-resistant Staphylococcus aureus and molecular cloning of mec-specific DNA. $J$ Bacteriol 1986; 165: 373-378.

37. Udo EE, Grubb WB. Transposition of genes encoding kanamycin, neomycin and streptomycin resistance in Staphylococcus aureus. I Antimicrob Chemother 1991: 27 $713-720$. 